\title{
The Irish Journal of Psychological Medicine: expanding horizons, moving on
}

\author{
B. D. Kelly* \\ Department of Adult Psychiatry, UCD School of Medicine and Medical Science, University College Dublin, Mater Misericordiae \\ University Hospital, Dublin, Ireland
}

First published online 26 October 2015

The Irish Journal of Psychological Medicine was founded in 1982 by Dr Mark Hartman (1942-1994) (McGennis, 1994). Dr Hartman studied medicine in Trinity College Dublin, where Professor Peter Beckett (1922-1974), first professor of psychiatry at Trinity (Webb, 2011), described him as 'the best student in his class' (McClelland, 1994).

Among the myriad accomplishments of his career in psychiatry (Kelly, 2012), Dr Hartman founded the Irish Journal of Psychological Medicine in 1982. Dr Hartman brought enormous vision and drive to the undertaking, travelling to Northern Ireland and England to seek out submissions, and inviting international speakers to Ireland in order to obtain more papers.

In order to produce the Journal itself, Dr Hartman designed original computer software and programmes, and was determined from the outset that the Journal would embrace new technologies such as the internet, even when the internet was in its early infancy. Following its foundation, Dr Hartman oversaw the establishment of a circulation base for the Journal, remarkable growth in circulation, broad-based scientific indexing and the stocking of the Journal in libraries around the world. From the outset, the Irish Journal of Psychological Medicine was a truly international creation.

In 1994, following the untimely death of Dr Hartman, Professor Brian Lawlor became editor-in-chief. On appointment, Professor Lawlor explicitly renewed the Journal's commitment to its central objectives: disseminating the results of original scientific research to a national and international readership; expressing the unique identity of Irish psychiatry; and underscoring the importance of cross-cultural differences in psychiatry (Lawlor, 1994). Over the following years, the Journal continued to publish national and international research papers, as well as editorials, review papers, case reports and book reviews.

* Address for correspondence: Professor B. D. Kelly, Department of Adult Psychiatry, UCD School of Medicine and Medical Science, University College Dublin, Mater Misericordiae University Hospital, 62/63 Eccles Street, Dublin 7, Ireland.

(Email: brendankelly35@gmail.com)
Journal format was also revised and the Journal awarded the annual John Dunne Medal, established in honour of Professor John Dunne, president of the Royal Medico-Psychological Association in 1955 and first professor of psychiatry at University College Dublin (Dunne, 1956; Reynolds, 1992; Kelly, 2005). The John Dunne Medal is still awarded annually to a trainee from Ireland or the United Kingdom, who has made a significant contribution (not necessarily as first author) to an original paper published by the Journal over the previous year. Over the past two decades, the John Dunne Medal has come to symbolise excellence and originality in the field of psychiatric research.

In 2010, I became editor-in-chief (Kelly, 2010), following periods as trainee editor (2004-2008) (Kelly, 2004) and deputy editor (2008-2010). This was an especially exciting period for the Journal and for Irish psychiatry, not least because the College of Psychiatry of Ireland (now College of Psychiatrists of Ireland) had emerged as an organisation in 2009 when three former bodies merged: the Irish College of Psychiatrists (a division of the Royal College of Psychiatrists in the United Kingdom), the Irish Psychiatric Association, and the then training body for psychiatry, the Irish Psychiatric Training Committee.

The College is now the professional body for psychiatrists in Ireland and the sole body recognised by the Medical Council and Health Service Executive (public health-care provider in Ireland) for competence assurance and training in psychiatry. The College offers membership, for psychiatrists and trainees, of an Irish institution that has now become the clear voice of psychiatry in Ireland (www.irishpsychiatry.ie).

In conjunction with its representative, training and advocacy roles, the College has a growing role in promoting and encouraging research, with a view to generating an improved evidence base for psychiatric practice. In this respect, the College is assuming at least some of the roles envisioned in long-standing calls for a research-oriented Irish Institute of Psychiatry, which has not yet materialised as such in Ireland (Clare et al. 1990; Daly, 1990). 
Following the emergence of the College in 2009, and given its myriad roles, it was apparent that the College would need a journal in order to strengthen the College's participation in the international research community and assist the College in shaping and improving standards of mental health care. In 2012, the Irish Journal of Psychological Medicine duly became the official research journal of the College.

Since then, the Journal has continued to publish highquality original research from around the world. These original data papers still form the central focus of the Journal, supplemented by briefer reports of smaller research projects, audit cycles and various other kinds of papers that reflect different approaches to research, practice and education. The Journal has also remained committed to publishing case reports and historical papers examining key topics in the histories of psychiatry in Ireland and elsewhere.

The years since 2010 have also seen substantial changes in journal format in partnership with our new publisher, Cambridge University Press. There has been a large increase in Journal usage and distribution; the majority of the Journal archive is now available online in one location, with additional link out functionality (journals.cambridge.org/ipm); and author survey feedback is highly positive.

In addition, the Journal has recently introduced Altmetrics, a system which measures the impact of papers beyond simply citations. Altmetrics tracks the sharing and discussion around research papers, considering social media sites, news outlets, government policy documents and other sources for mentions of scholarly articles. It then uses this information to calculate a score for each article. On this basis, each article published in the Journal is now assigned a score, which is visible on the Journal website at the article level, so authors can keep track of where and how their paper is being shared.

There have also been various other advances and innovations at the Journal over this period, with a reformulated international editorial board playing an increasing role in Journal policy and development. In March 2011, we published a special supplement dedicated to head shop drugs (Kelly, 2011; O'Keefe, 2011) and in March 2015 we published our first special issue, which was devoted to youth mental health, edited by Dr John Lyne and Professor Mary Cannon (Lyne \& Cannon, 2015).

Ultimately, all of these innovations and improvements have one central purpose: to inform and improve the evidence base for mental health services, so as to enhance understanding and the quality of mental health care provided to those who need it. In the end, that's what matters most.

As I step down as editor-in-chief, after 12 enjoyable years working closely with the Journal, I am confident that the new editor-in-chief will, with your support and the backing of the College, continue to achieve this goal.

\section{Acknowledgements}

None.

\section{Financial Support}

This research received no specific grant from any funding agency, commercial or not-for-profit sectors.

\section{Conflicts of Interest}

None.

\section{References}

Clare A, Daly RJ, Dinan TG, King D, Leonard BE, O’Boyle C, O'Connor J, Waddington J, Walsh N, Webb M (1990). Advancement of psychiatric research in Ireland: proposal for a national body. Irish Journal of Psychological Medicine 7, 93.

Daly RJ (1990). Community psychiatry and the National Institute of Mental Health. Irish Journal of Psychological Medicine 7, 5.

Dunne J (1956). The contribution of the physical sciences to psychological medicine. Journal of Mental Science 102, 209-220.

Kelly BD (2004). Investing in the future. Irish Journal of Psychological Medicine 21, 111.

Kelly BD (2005). Physical sciences and psychological medicine: the legacy of Prof John Dunne. Irish Journal of Psychological Medicine 22, 67-72.

Kelly BD (2010). The Irish Journal of Psychological Medicine: looking to the future. Irish Journal of Psychological Medicine 27, 170-171.

Kelly BD (2011). Head shop drugs: they haven't gone away. Irish Journal of Psychological Medicine 28, S1.

Kelly BD (2012). The Irish Journal of Psychological Medicine and the College of Psychiatry of Ireland. Irish Journal of Psychological Medicine 1, 3-6.

Lawlor BA (1994). Quo vadis? Irish Journal of Psychological Medicine 11, 107.

Lyne J, Cannon M (2015). A special issue: highlighting the youth mental health agenda. Irish Journal of Psychological Medicine 32, 1-2.

McClelland R (1994). An appreciation of Dr Mark Hartman, founder and editor-in-chief of the Irish Journal of Psychological Medicine. Irish Journal of Psychological Medicine 11, 4.

McGennis A (1994). Obituary: Mark Hartman. Psychiatric Bulletin 18, 442.

O'Keefe C (2011). Medical problems caused by 'legal highs' continue. Irish Examiner, 12 May.

Reynolds J (1992). Grangegorman: Psychiatric Care in Dublin Since 1815. Institute of Public Administration/Eastern Health Board: Dublin.

Webb M (2011). Trinity's Psychiatrists: From Serenity of the Soul to Neuroscience. Trinity College: Dublin. 